\title{
Az európai menekültválság egészségügyi kérdései a Public Health Reviews 2016. július 8-án megjelent „Europe's collective failure to address the refugee" cikke alapján ${ }^{1}$
}

Health-related aspects of the European refugee crisis based on the article titeled „Europe's collective failure to address the refugee” published in Public Health Reviews on 8 July 2016

\author{
Szerzők: Kárpáti Tímea $₫$ \\ Nemzeti Egészségfejlesztési Intézet
}

Beküldve: 2016.02.21.

doi: $10.24365 /$ ef.v58i1.143

\begin{abstract}
Összefoglalás: Az Európába irányuló menekültáradat számos tagállamot eddig soha nem látott kihívás elé állított. A nemzetközi válaszlépések egyebek mellett arról is szólnak, hogy az egészségügyi ellátást minden menekült - de különösen a legkiszolgáltatottabb csoportok - számára folyamatosan biztosítsa. Azonban a migránsok egészségügyi szükségletei rendkivül heterogének, a különböző kulturális, egészség-kulturális, vallási és nyelvi háttérrel, betegségstruktúrával, orvoshoz fordulási szokásokkal illetve jogi státusszal rendelkező személyek számára nyújtott egészségügyi, valamint pszicho-szociális szolgáltatás újfajta ismereteket és készségeket igényel az egészségügyi dolgozóktól, szakemberektől.
\end{abstract}

Kulcsszavak: migráns, menekültügy, Európa, egészség, egészségügy

\begin{abstract}
The crowd of refugees targeting Europe has brought unprecedented challenge for many member states. International response include - among other measures - providing a continuous health care for all migrants, especially for the most vulnerable. However, migrants' health care needs are extremely heterogeneous. Health care and psycho-social support provided for people, with their diverse cultural, health-cultural, religious and linguistic background, illness structure, habits to take medical advice, and legal status; requires novel knowledge and skills from health care workers and other professionals.
\end{abstract}

Keywords: migrant, refugee crisis, Europe; health, health care

Az európai migrációs válság vagy más néven európai menekültválság kifejezéseket 2015 áprilisában használták először azzal a megrázó eseménnyel öszszefüggésben, amikor egy migránsokkal teli hajó elsüllyedt a Földközi tengeren Líbia partjainál, és ennek következtében több mint 700 ember vesztette életét. ${ }^{2}$

A napjainkban zajló migrációról számtalan kép és videófelvétel tudósít azzal a törekvéssel, hogy pillanatképet kaphassunk a válsághelyzetről; például ahogy családok sodródnak kis hajókban a tengeren, amikor szembenéznek a megaláztatással, ami az európai határokon fogadja őket, ahogyan a „szemétkempingekben” táboroznak (pl. a franciaországi Calais mellett), vagy azokat a hajóroncsokat mutatva, amelyeken az emberek csak a hullámsírig juthattak el. Az a felvétel, amin a török tengerparton egy rendőr éppen felemeli a szíriai kisfiú, Alan Kurdi holtestét, örökre egybeforrt a menekültügyi válsággal, és a szolidaritás szimbólumává vált. ${ }^{3}$ 
Ezeket a képeket és a tudósításokat látva gyakori, hogy a migrációra egy jelenségként tekintünk, ugyanakkor figyelmen kívül hagyjuk - kivéve olyan személyes megrázó esetekben, mint amilyen például Alan Kurdié -, hogy tulajdonképpen minden egyes menekült, aki már átkelt Európába, vagy aki próbálkozás közben meghalt, valójában egy személy, saját személyes történetével, életútjával.

A különböző fegyveres konfliktusok, politikai és/vagy vallási üldöztetés, és az ezekből következő gazdasági ellehetetlenülés miatt menekülők vándorlása számtalan kérdést vetett és vet fel folyama- tosan nemzetközi, nemzeti és egyéni szinten is, melyek közül jelen cikkben az egészségügyi, illetve a menekültek egészségi állapotát érintő, és az azt befolyásoló problémák kerülnek ismertetésre, elsősorban a címben jelölt forráscikket alapul véve.

Az Európába érkező menekültek - többségük Szíriából, Afganisztánból és Eritreából indul útra - főként Közel-Keletről, Afrikából, a Balkánról és Közép-Ázsiából igyekeznek az Európai Unió területére jutni a Földközi-tengeren és a Balkánon kialakult, jól definiálható menekültútvonalakon keresztül. [1. ábra]

\section{1. ábra: Az Európába tartó bevándorlási útvonalak térképe}

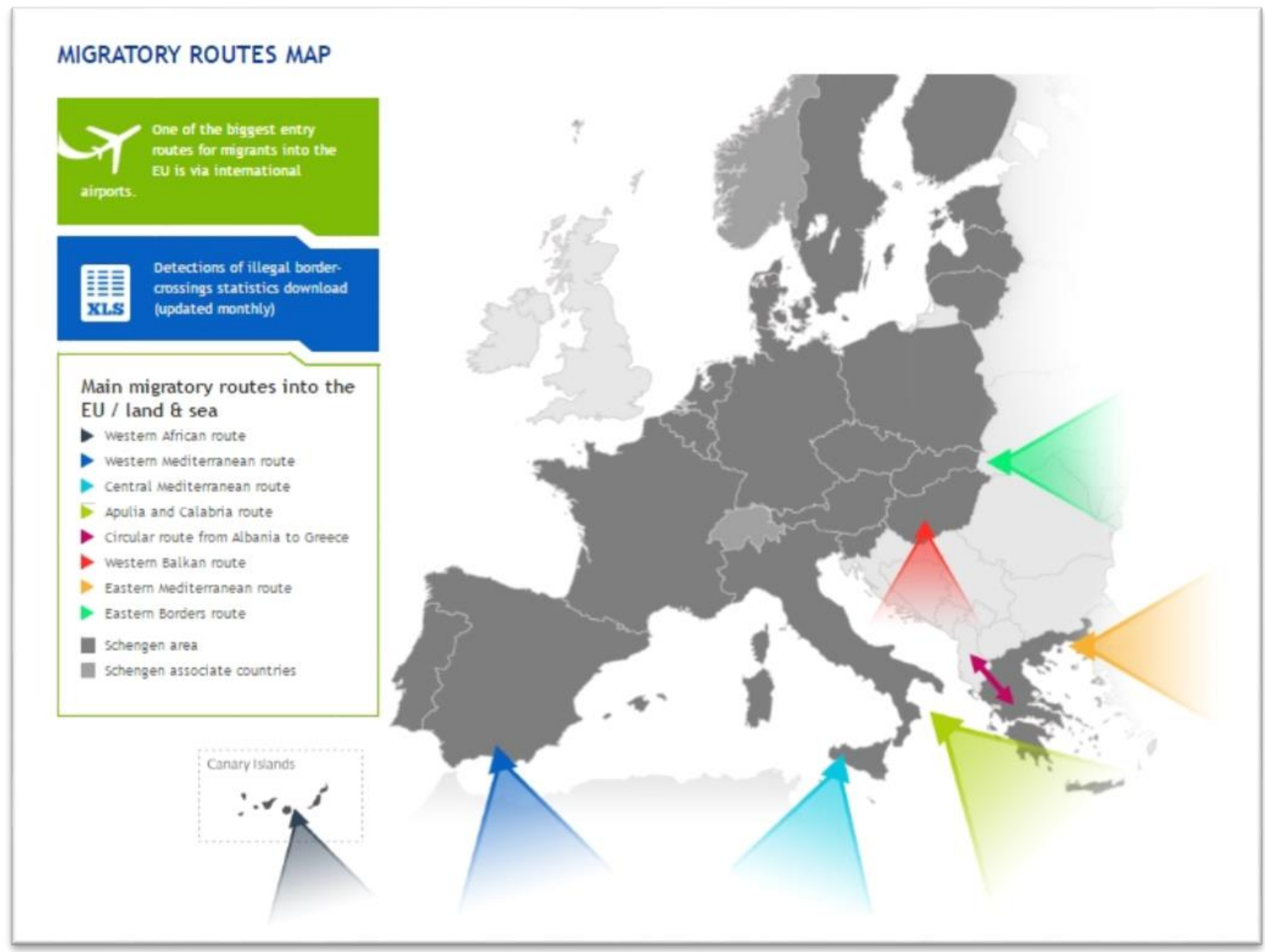

Forrás: FRONTEX, Európai Határ- és Partvédelmi Ügynökség 4

Az Eurostat szerint az Európai Unió tagállamaihoz 2014-ben 626000 menekültkérelmet nyújtottak be (frissebb összesített adat 2017 augusztusában várható), és közel 360000 kérelemről hoztak döntést, ebből 160000 fogadtak el első körben, további 23
000 pedig fellebbezés után. 45\% volt az elsőre jóváhagyott és $18 \%$ a fellebbezés után elfogadott kérelmek aránya. ${ }^{5,1} \mathrm{~A}$ menedékkérelmek kétharmadát négy tagállamhoz: Németországhoz, Franciaországhoz, Svédországhoz és Olaszországhoz nyújtották 
be, azonban a lakosságukhoz viszonyítva arányaiban a legtöbb menedékkérő Svédország, Ausztria és Magyarország területére érkezett. ${ }^{6}$

A humanitárius szervezetek megfigyelései és tapasztalatai szerint sok menekült a vándorlás során nem jut még az alapvető egészségügyi alapellátásokhoz sem - beleértve az anya és a gyermek egészségügyi ellátását is -, ugyanis orvosi kezelésről nagyon nehéz gondoskodni, miközben országhatárokat lépnek át. Több, főként ázsiai országban óriási korlátozások vannak érvényben a - már amúgy is korlátozott jogosultságokkal rendelkező, papírok nélküli - menekültekre vonatkozólag. A gondoskodás, az ellátás általában a kis, önkéntes csoportokra, valamint a nemzetközi humanitárius szervezetekre marad, mint pl. a Médecins du Monde, Médecins Sans Frontières, és a Save the Children. ${ }^{7,8,9}$ Ők az orvosi ellátáson túl mentális segítséget is nyújtanak, pszicho-szociális rehabilitációt végeznek a vonatállomásokon, menekülttáborokban, illetve a határokon felhúzott mobil klinikákon. Ezekre a szolgáltatásokra azért van szükség, mert a háború sújtotta térségekből érkezőket már a menekülést megelőzően is súlyos traumák, fokozott pszichés terhelések érték, és mindez - rendszerint - a menekülés közben, illetve után is folytatódik. A tranzit/fogadó/célországba való integrációs folyamat, illetve a munkakeresés során is komoly lelki teher éri a migráns háttérrel rendelkezőket a váratlan problémák, korábban ismeretlen körülmények és az ebből fakadó akadályok kapcsán. Például nehezíti a helyzetüket, hogy le kell küzdeni a nyelvi korlátokat, az elszegényedést, az egészségügyi biztosítás és az egészségügyi rendszer ismeretének hiányát, a betegségek eltérő értelmezéseit, a kezelés másságát, a jövőt illető bizonytalanságot stb.

Az Európába irányuló folyamatos menekültáradat számos tagállamot eddig soha nem látott kihívás elé állított. A nemzetközi válaszlépések egyebek mellett arról is szólnak, hogy az egészségügyi ellátást minden menekült - de különösen a legkiszolgáltatottabb csoportok - számára folyamatosan biztosítsa az Egészségügyi és Élelmiszerbiztonsági Főigazgatóság az EU Egészségügyi Biztonsági Bizottságán keresztül a tranzit- vagy célországként különösen nagy migrációs nyomás alatt álló tagállamokban, illetve ennek megvalósítása érdekében szoros együttmúködés folyik a Bizottság, az uniós ügynökségek és a fő civilés nemzetközi szervezetek között. ${ }^{10}$
Ennek keretében például összeállítottak egy egységes ellenőrző listát, amellyel az uniós fogadóállomásokon és fogadóterületeken a szakemberek felmérhetik az odaérkező migránsok egészségi állapotát, felállíthatják kórtörténetüket, a rászorulókat megfelelő egészségügyi ellátásban részesíthetik.

Az Európai Bizottság elnöke, Jean-Claude Juncker azonban hangsúlyozza, hogy ezek az intézkedések kizárólag a menekültek egészségének megóvását szolgálják, és nem abból az alaptalan félelemből fakadnak, hogy az Európába érkezők fertőző betegségeket terjeszthetnek, visszaélhetnek az ellátórendszerek szolgáltatásaival, és leterhelik az egészségügyi rendszereket. „Ne feledjük: a hazájukból menekülők egészsége van veszélyben, nem az uniós polgároké." 6

Az Európai Unióba érkező személyek egészségügyi szempontból a saját, földrajzilag tőlünk távoli hazájuk megbetegedési profilját tükrözik, amelyek számos tekintetben eltérnek az európai országokétól. Nagy különbségek mutatkoznak a migránsok származási helyén múködő közegészségügyi rendszerek fejlettségi szintjében is, ugyanis van olyan anyaország, amelyben ez nagyon kezdetleges, de például Szíriában jól fejlett volt, ugyanakkor a válság következtében már teljesen összeomlott. A nagyon eltérő háttér miatt is a migránsok egészségügyi szükségletei rendkívül heterogének, az ellátási igényük függ továbbá a migrációs folyamat adott szakaszától, társadalmi státuszuktól, tudatosult igényeiktől, egészségmagatartásuktól, a tranzit- vagy a célország nyelvének ismeretétől illetve annak hiányától, idegen nyelvismeretüktől ( $p l$. angol nyelvhasználat szintjétől), valamint kulturális és vallási sajátosságoktól is. Az Egészségügyi Világszervezet (WHO) a Szicíliai Regionális Tanács pénzügyi támogatásával létrehozott Európai Egészségügyi és Migrációs Tudásközpont megalapításának (2016. november) célja az volt, hogy segítse azon országok munkáját, melyek közvetlenül kapcsolatba kerülnek a migrációs egészségüggyel. A WHO európai regionális igazgatója szerint a külföldiek egészségügyi problémáinak kezeléséhez széles körű és pontos információkra van szükség, a menekülteket befogadó országoknak képeseknek kell lenniük a fertőző és nem fertőző betegségek azonnali ellátására. ${ }^{11}$

Azonban az egészségügyi szolgáltatások igénybevételét gazdasági, szociális, kulturális és nyelvi korlátok akadályozhatják, de ebben közrejátszhat az elérhető támogatással kapcsolatos ismeret hiánya, az 
egészségügyi ellátórendszerrel összefüggésben az általános tájékozatlanság, a navigáció nehézségei. A nyelvi, kulturális és kommunikációs sajátosságok gondként jelentkeznek az ellátók oldalán is, illetve az a tény is, hogy a szolgáltatók számára e feladat újszerü. Emellett egyes joghézagok is nehezítik a migránsok egészségügyi gondozását. Az egészségügyben dolgozó orvosok és szakalkalmazottak jelentős részének interkulturális felkészületlensége és tájékozatlansága azt eredményezi, hogy gyakran nem ismerik és nem értik a migránsok sajátos szükségleteit és elvárásait. Mindez kölcsönös bizalomhiányhoz vezethet, ami akár a kezelések sikerességét is befolyásolhatja.

Azokat a külföldieket, akik hivatalos eljárás keretében menekültként való befogadásukat kérik Magyarországon (a továbbiakban: bevándorló), a befogadás során ellátások és támogatások illetik meg rászorultságuk, illetve egyéni élethelyzetük függvényében. Ezek a befogadás anyagi feltételeinek biztosítása ( $p l$. a befogadó állomáson nyújtott elhelyezés és ellátás, részesítés adományokból, utazási kedvezmények, köztemetés költségeinek viselése), egészségügyi ellátás, oktatási-nevelési költségek megtérítése, pénzbeli támogatások, ennek körében az ország végleges elhagyásának támogatása. ${ }^{12}$

A Magyar Bevándorlási és Menekültügyi Hivatal tájékoztatása szerint, amennyiben az a bevándorló, aki nem áll társadalombiztosítási jogviszonyban és szociálisan rászorult, meghatározott egészségügyi szolgáltatásokra térítésmentesen jogosult. $A z$ egészségügyi alapellátást a befogadó állomáson, vagy menekültügyi őrizetben elhelyezett külföldiek helyben, magánszálláson lakó kérelmezők a területi ellátási kötelezettséggel egészségügyi szolgáltatást nyújtó háziorvosnál vehetik igénybe. Sürgős szükség esetén igénybe vehetik a járóbeteg-szakellátást (pl. vizsgálat, gyógykezelés stb.), illetve a fekvőbeteggyógyintézeti ellátást is (gyógykezelés, műtéti beavatkozás, gyógyszer, kötszer költsége, stb.) a területi ellátási kötelezettséggel múködő egészségügyi szolgáltatónál. Sürgős szükségnek minősül az egészségi állapotban bekövetkezett olyan változás, amelynek következtében azonnali egészségügyi ellátás hiányában a beteg közvetlen életveszélybe kerülne, illetve súlyos vagy maradandó egészségkárosodást szenvedne. A bevándorló a járóbeteg-szakellátást vagy a fekvőbeteg-gyógyintézeti kezelést követően a betegségből való gyógyulásig, illetve állapotának stabilizálódásáig szükséges vizsgálatokra és gyógykezelésre, gyógyászati segédeszköz igénybe vételére is térítésmentesen jogosult, valamint betegszállításra abban az esetben, ha egészségügyi állapota miatt a szállítás másként nem oldható meg. Sürgősségi fogászati ellátás és fogmegtartó kezelés, terhes-gondozás és szülészeti ellátás (továbbá meghatározott esetekben a terhesség megszakítását célzó beavatkozás), valamint a „közgyógyellátásra jogosultak" részére térítésmentesen, 90\%-os vagy 100\%-os társadalombiztosítási támogatással rendelhető gyógyszer, gyógyászati segédeszköz és kötszer felírása szerepel az egészségügyi szolgáltatások listáján, amelyekre szintén jogosult a bevándorló. Kiemelt szerepet kapnak még a védőoltások is, melyek életkorhoz kötötten, de csak a kötelező oltások esetében térítésmentesek.

Az úgynevezett Dublini Eljárás a migráció során szétszakadt és a különböző tagállamokban menedékjogot kérő családtagok együttélését, illetve a kísérő nélküli kiskorúak védelmének biztosítását is elrendeli a 604/2013/EU Parlamenti és Tanácsi Rendelet (Dublin III Rendelet) 4. cikke, amely lehetővé teszi a családegyesítést, így a családtagok menekültkérelmét együtt bírálják el. ${ }^{13}$ Ezen kívül a Dublini Eljárás során megállapításra kerülhet egy olyan, a bevándorlást kérelmező külföldi tartózkodásától eltérő európai tagállam felelőssége is, amelyben valamely szoros családtagjának menekülteljárása már korábban megkezdődött, vagy ahol családtagja már jogszerúen tartózkodik, vagy menekültstátusszal rendelkezik. Ez azért jelentős rendelkezés, mert nagyon gyakori, hogy a gyerekek, a fiatalok el vannak szeparálva a családjuktól, más-más országban tartózkodnak, ezáltal korlátozott a védelmük. Az Europol becslése szerint hozzávetőlegesen 10000 kísérő nélküli gyermek tûnt el a krízis alatt, és emelkedik a nemi alapú erőszakos esetek száma is. ${ }^{14,2}$

A különböző kulturális, egészség-kulturális, vallási és nyelvi háttérrel, betegségstruktúrával, orvoshoz fordulási szokásokkal és jogi státusszal rendelkező személyek számára nyújtott egészségügyi, valamint pszicho-szociális szolgáltatás újfajta ismereteket és készségeket igényel az egészségügyi dolgozóktól, szakemberektől, melyre a jelenlegi képzésük nem készíti fel őket.

Ezek közül talán az egyik legfontosabb az interkulturális kompetencia, amely elengedhetetlen az orvos és a beteg közötti kölcsönös bizalmi légkör kialakításához. ${ }^{15}$ A kulturális és vallási elköteleződések egészségügyi kihatásainak ismerete nélkül ez a bi- 
zalmi kapcsolat nem fog kialakulni akkor sem, ha az ellátást végző orvos szakmailag kiváló. Ideális esetben (és közös nyelv híján) az orvos és betege közti kommunikációt tolmács segíti, azonban a szakembereknek azt is meg kell tanulniuk, mit és milyen módon lehet kommunikálni egy ilyen helyzetben. Ezen a körülményen igyekszik javítani a migrációs egészségügyi szakemberek képzésére való törekvés, melyről megállapodást kötött a Pécsi Tudományegyetem (PTE) és a Kremsi Donau-Universität. ${ }^{16} \mathrm{~A}$ tervek szerint az Európában úttörő jellegú, angol nyelvű mesterképzésen évfolyamonként 20-25 egészségügyi dolgozó oktatása történik. A hallgatóknak járványügyi, kutatási, közegészségügy-ellátási, foglalkozás-egészségügyi, mentálhigiéniai és egyéb olyan ismereteket is tanítanak, amelyek segítik az egészségügyi szakembereket a különböző kultúrkörökből érkező migránsokkal való kommunikációban. A képzés indokoltságát támasztja alá, hogy a migrációs folyamat felerősödése elengedhetetlenné teszi az egészségügyi szakemberek ilyen irányú felkészítését, valamint az a tény, hogy a migránsoknak a napi egészségügyi ellátása is speciális felkészültséget kíván. További kihívást jelent, hogy olyan országokból érkeznek a bevándorlók, ahol a lakosság a védőoltásokat nem olyan széles körben kapja meg mint Európában, így van esély évtizedek óta jelen már nem lévő betegségek újbóli előfordulására.
Szintén a szakemberek képzésében előrelépést jelenthet az a széleskörü tananyag-fejlesztési C2ME/Competence (Culturally Competent en Medical Education) projekt is, amelyben a Pécsi Tudományegyetem - ÁOK, Múveleti Medicina Tanszék Migrációs-egészségügyi Tanszéki Csoportja - konzorcium partnerként múködik közre többek között az University of Amsterdam, Leicester, Antwerpen, Edinburgh, Copenhagen, Norwegian Centre for Minority Health Research (NAKMI), University of Maryland, Hopitaux Universitaires de Geneve egyetemekkel. ${ }^{17}$

A pécsi kutatók ráadásul igen fontos területen játszanak vezető szerepet, hiszen az Egészségügyi Világszervezet Európai Regionális Bizottságának 2016. szeptemberi találkozójának éppen a migrációs egészségügy volt a kiemelt témája, ahogy azt annak szlogenje is jelzi: „Nem létezik közegészségügy a menekültek és migránsok egészsége nélkül”. ${ }^{18} \mathrm{Dr}$. Allan Krasnik, az Európai Közegészségügyi Társaság migráns- és etnikai kisebbség-egészségügyi szekciójának elnöke úgy fogalmazott, hogy a bevándorlóknak mindenképpen segítséget kell nyújtani, és „nem járványként, hanem emberként kell tekinteni rájuk". ${ }^{19}$ Nem szabad, hogy úgy lássuk őket, mint akik csak félelmet gerjesztenek és fertőzéseket hoznak, hanem lehetőségként, hogy be tudnak integrálódni egy másik ország társadalmába és segíthetik azt.

\footnotetext{
${ }^{1}$ B. Roberts, A. Murphy, M. McKee: Europe's collective failure to address the refugee crisis https://publichealthreviews.biomedcentral.com/articles/10.1186/s40985-016-0015-6 (Elérve: 2017.02.10.)

2European migrant crisis: Shipwrecks 'kill up to 700 migrants' BBC News. (2016. május 29.) http://www.bbc.com/news/world-europe-36408029 (Elérve: 2017.02.10.)

${ }^{3}$ The death of Alan Kurdi: one year on, compassion towards refugees fades https://www.theguardian.com/world/2016/sep/01/alan-kurdi-death-one-year-on-compassion-towards-refugees-fades (Elérve: 2017.02.20.)

${ }^{4}$ Migratory routes map: http://frontex.europa.eu/trends-and-routes/migratory-routes-map/ (Elérve:2017.02.10)

${ }^{5}$ Erostat newsrelease (2015. május 12.) http://ec.europa.eu/eurostat/documents/2995521/6827382/3-12052015-APEN.pdf/6733f080-c072-4bf5-91fc-f591abf28176 (Elérve: 2017.02.10.)

${ }^{6}$ Chris Harris: Data raises questions over Eus attitude towards asylum seekers: http://www.euronews.com/2015/05/14/data-raises-questions-over-eu-s-attitude-towards-asylum-seekers (Elérve: 2017.02.10.)

${ }^{7}$ Médecins du Monde: http://www.medecinsdumonde.org/fr (Elérve: 2017.02.24.)

${ }^{8}$ Médecins Sans Frontières: http://www.msf.org/ (Elérve: 2017.02.24.)

${ }^{9}$ Save the Children: http://www.savethechildren.org/site/c.8rKLIXMGIpl4E/b.6115947/k.B143/Official USA Site.htm (Elérve: 2017.02.24.)

${ }^{10} \mathrm{M}$. Seychell: Refugee crisis: Noble words need to be followed by concrete action http://ec.europa.eu/health/newsletter/162/focus newsletter hu.html (Elérve: 2017.02.10.)
} 
${ }^{11}$ WHO launches European Knowledge Hub on Health and Migration (2016.11.15.) http://www.euro.who.int/en/healthtopics/health-determinants/migration-and-health/news/news/2016/11/who-launches-european-knowledge-hub-onhealth-and-migration (Elérve: 2017.02.10.)

${ }^{12}$ Bevándorlási és Menekültügyi Hivatal: Menedékkérők ellátása: http://www.bmbah.hu/index.php?option=com k2\&view=item\&layout=item\&id=421\&ltemid=392\&lang=hu (Elérve: 2017.02 .10 .)

${ }^{13}$ Az Európai Parlament és a Tanács 604/2013/EU rendelete (2013. június 26.): http://eur-lex.europa.eu/legalcontent/HU/TXT/?uri=CELEX\%3A32013R0604 (Elérve: 2017.02.10.)

${ }^{14} \mathrm{H}$. Merriman: Why are 10,000 migrant children missing in Europe? (2016. október 12.)

http://www.bbc.com/news/world-europe-37617234 (Elérve: 2017.02.10.)

${ }^{15}$ Várhegyi Vera, Stephanie Nann: Az interkulturális kompetenciák azonosítása http://www.adameurope.eu/prj/4407/prd/1/1/WP2-WP3 Final study HUN.pdf (Elérve: 2017.02.20.)

${ }^{16} \mathrm{Az}$ Egészségügyi Világszervezet (WHO) „Panorama” című kiadványának különleges száma „Migráció és Egészségügy” témában (2017. 02.09.) http://aok.pte.hu/hu/hirek/hir/9020 (Elérve: 2017.02.20.)

${ }^{17}$ Hundelson et al.: The challenges of integrating cultural competence into undergraduate medical curricula across Europe: experience from the C2ME „Culturally competent in medical educatin” project http://www.mededpublish.org/manuscripts/365/v1\#thec2meproject (Elérve: 2017.02.10.)

${ }^{18}$ Megállapodás aláírása a Migrációkutató Intézettel (2016. szeptember 13.) http://aok.pte.hu/hu/hirek/hir/8629 (Elérve: 2017.02.10.)

${ }^{19}$ A. Krasnik: Migrants'access to health services http://publichealth.ku.dk/staff/?pure=en\%2Fpersons\%2Fallankrasnik(d1a42a6c-e3d6-4d5b-803e-e80b13314d46).html (Elérve: 2017.02.10.) 